\title{
Zuid Midden Timor under the Dutch Control 1905-1942
}

\author{
Sarlota Naema Sipa," A. M. Djuliati Suroyo, Endang Susilowati \\ Master Program of History, Faculty of Humanities, Diponegoro University \\ "Corresponding Author: 5arlota.sipa@gmail.com
}

\begin{abstract}
This study is aimed at retracing the Dutch colonial government in South Middle Timor or Zuid Midden Timor in the beginning of $20^{\text {th }}$ century. Intending to expand its controlled territories, to exploit the sandalwood trade and introduce Christianity, the colonial government then domiclied in Kupang entered the inland parts of Timor island, to be prescisely in Received: Molo in 1905. The Ducth colonial government defeated the local meos 12 April 2017 (soldiers), the Molo meo, Amabuan meo and the Amanatun meo. These three regions were later formed as a governmental administration zone Accepted: by the East Indies, equivalent to a landschaap and were later combined in 18 May 2017 an onderafdelling-level administration unit called Zuid Midden Timor, with Molo as its capital city. As the capital city, Molo housed all public administration affairs, markets and shops, which were all centered in Molo. Until the end of the Dutch control in 1942, the Dutch colonial government had left its influences in culture, education, social aspects and governmental politics.
\end{abstract}

Keywords: Zuid Midden Timor; Colonial power; Administrative changes.

\section{Introduction}

The island of Timor has been known by ancient merchants for its sandalwood trade. The sandalwood business actuall took place in inland regions of Timor island, because its geographhic conditions support good growth of sandalwood trees at 1 , 500 to 2000 meters above sea level. The first merchants recorded to have entered Timor islan were the Chinese merchants, traveling to the inland regions via the rivers located in the island and conducted barters for sandalwood with the local chiefs, the amaf. This sandalwood trade spurred the trade of other commodities, such as slaves and weapons and also invited/attracted merchants from Java and European traders to come to Timor island. The Portugese traders landed in Timor islan for the first time in 1514 with the intent to spread their religion and to exploit/utilize sandalwood. They built a fortress on the island of Solor, which was named Henriques Bastion/ Fortress. The exploitation of sandalwood only began between 1535 and 1556 with the Portegese's seat of control located in Solor (Widiyatmika, 2014:15). Having built cooperation with thelocal communities, the Portuguese built 
another fortress in Kupang, named Concordia Bastion. The fast growing sandalwood trade in the world market attracted the government of the Verenigde Oost-Indische Compagnie (VOC) to come to Timor island and monopolize control. On April 20 $0^{\text {th }}$, 1613 the VOC seized the Portuguese bastion at Solor and forced the Potugues to go to Larantuka. In 1646 also successfully took control of another Portuguese fortress in Kupang benteng Portugis di Kupang (Widiyatmika, 2010:47-48). VOC issued a new regulation stating that sandalwood could be traded only if the trader paid one third of the value of the sandalwood being traded to VOC, this regulation did not work well. After VOC was dissolved and replaced by the East Indies in 1810, both the Portuguese and VOC had not enter the inland of Timor (Widiyatmika, 2014:29). Competition in trade, politics and religion between the Portuguese and VOC in Tomor gave the rise to Catholicism, Protenstant Christianity and education on the island of Timor. Portuguese came to spread their religion and engage in commerce was followed by the VOC traders who combined trade, economy, politics and power eventually influenced the people of Timor with their way of life and culture, especially in Molo.

In 1816 under the decree of Resident Hazaart, the government of East Indies built a supporting zone in Babau (near Kupang). This decision was considered to be vital since Kupang was frequently unsafe because of the threats from the local kings in the inland in the inland regions of Timor. This supporting zone was later inhabited by immigrants from the island of Rote and Sabu, who acted as the intelligence agents for the East Indies government. The immigrants from Rote initially numbered 300400 who originally came Ingu Fao Termanu region.Between 1818 and 1819 another 400-500 people were sent in from Hoi Ledo Termanu to Pariti. This migration of Rote people from was intended to lessen the power of the king of Termanu, whose power was vast. Until 1870 the number of people from Rote had increased along the northern coastal areas of Kupang Bay up to Naikliu in North Amfoang (Widiyatmika, 2014:98). The Government of East Indies and the Portuguese decided to fix the borders for their control on Timor; the eastern part of Timor was under the Portugese and the western part of the island belonged to the Dutch control. At the beginning of the twentieth century, the Government of the Dutch East Indies then having its seat in Kuang thought that they needed to expand their controlled territory on the island of Timor,so that they might be able to exploit sandalwood trade and spread their religion, Protestantism. Consequently, in 1905 the Government of the Dutch East indies entered the inland regions of Timor and set Molo as their governmental seat. The purposes of the establishment of Molo government were multifaceted. First, Molo was close to the border to the Portuguese controlled/occupied territories (the eastern part of Timor) and to the Dutch occupied region (western part of Timor). Second, the geographical region of Molo was totally diferrent from other areas on the island of Timor as Molo was situated at an elevation of 1500 to 2000 meters above sea level, making it a very suitable place for sandalwood trees to grow well. Third, the transactions of sandalwood actually took place in the inland region of the island of Timor. 
In 1905, Dutch troops entered this inland region of Timor and started the attacts to the local meo (soldiers). These meos counter-attacked them, and two wars, widely called by the local people as Bipolo and Nefobesak wars broke out. In these wars the local meo were defeated. One of the decendents of Sonbai king, named Boab Sonbai was invited by the Governement of the East Indies domiciled in Kupang to discuss cooperation but at his arrival in Kupang, the East Indies Dutch Government under Resident (Mayor) Hazart kidnapped him and exiled him to Waingapu. After establishing Molo and set up a Kapan as a pioneering zone for the Government of the East Indies in he inland Timor, dutch troops launched other attacks in the regions of Amanuban Amanatun. These wars are called by the local people as Niki-niki War, Kolbano War and Fotilo War. Again, in these wars the local soldiers (meo) were defeated leading to the greater control of wider territories by the Government of the East Indiest in the inland regions of Timor island. Using the devide et impera (goatfight tactic), the Government of East Indies restructured the afdeling zones of Timor. The Dutch divided the territories under the control of Sonbai king of into smaller kingdoms (landschaap). Some of the small kongdoms established included the Molo, Amanuban and Amanatun kongdoms. These three small kingdoms (landschaap) were then combined into a Dutch Governmental Administration unit equal to an onderafdeling which was later named Zuid Midden Timor. Other than building schools as the facilities to introduce Christianity and baptizing people who surrendered to be baptized, the Government of East Indies also exploited the sandalwood.

This article is meant to re-open the history of Zuid Midden Timor under the control of the Dutch East indies Government and the impacts of the administration of the The Dutch East Indies Government there. The article is concerned with the following topics: (1)The social life, economy and politics of Molo people prior to the arrival of Dutch (2) The process of the Dutch expansion and colonialization inZuid Midden Timor? (3) The impacts of the Dutch government adminstration on the people of Zuid Midden Timor?

\section{Method}

The method used in this study is the historical method, composed of four phases: data collectio, (heuristik), criticism, interpretataion and historiography. After the data have been collected (heuristik), a criticism is applied after the sources have been selected, both the external and inter cirticims; the exernal criticism is used to detemine the the autheticity of the sources, the internal criticm to obtain the credbility of the sources. These historical data are then anlyzed using the sociopolitical approach to get the historical fatcs which are lated combined to creat a historical event through histiriography stages. This study employsa number of colonial archive files and other sourcs, both relevan and containig the historical fatcs. The sources used herein include, inter alia:Gezaghebbers in Kolonial Zuid-Midden-Timor (voormalig Midden Timor), Regeeringsalmanak, Timor En Onderhoorigheden, Gedrukte Stukken van de Tweede Kamer der Staten-General (verklaring),Akte van Overeenkomst in 
Zake de Grens Tusschen de Landschaap Onderafdeelig West Midden Timor en Midden Timor, Noord Midden Timor en Midden Timor.

\section{Results and Discussion}

\section{Local Government System}

Origin of the Peoples of Zuid Midden Timor

Long before the arrival of the Portuguese and the Dutch in the western part of Tomor, the area of Molo had been inhabited by the Melus and Keujamas clans. According to the accounts of the mafefa (spokeman) the king of Molo was named Nicodemus Fobia and that the Melus and Keujamasclans both originated from eastern areas. The Melus was later invaded by other peoples who came later and was forced to cross the sea to the island of Alor, the Keujamas clan later moved to the western part of the island of Timor and lived as nomads (nomaden). Not all of these native peoples left the region, as the accounts from the local people's leaders/chiefs hold that some people were left behind and assimilated with the newcomers and the decendants of the native are still in existent up to the present. The first migrants were from Wehale kingdom in Belu. A decendant of Wehale kingdom named Maromak Oanhad three sons, Nai Suri (the first son), Nai Dawan (second son), and Nai Taek (the youngest/third son). These three sons were assigned by Maromak Oan to explore and take control of the entire land of Timor. The first son, Nai Suri, was assigned as ai Liurai (the war comander in chief) in Wehale kingdom, the second son, named Nai Dawan was assign to explore westward on the island of Timor through Noel Bikomi and finally arrived at the foot of Mount Mutis. This second son finally controlled the western parts Timor,in this case Molo. The youngest son, named Nai Taek, was assigned to explore eastward on the island of Timor. This third son later become the lord of the eastern regions of Timor which has been known as Likusaen kingdom by the people (Kase, 2004:10).

The people of the Zuid Midden Timor were actually divided into separate small clans, who lived under the rule of a clan chief and formed a social relationship based on kinship system. They then emerged as and named themselves the Atoni Meto. The tribal chief was also the head of the government (Parimarta, 2016:72-74). In the western part of Timor, in Molo, clans represent the major aspects in understanding the traditional government because clans are the basic social kinship. The Molos (Molo people) also knew an extended family concept, called nonot. A Nonot is illustrated to resembel the ratan (a type of runners). This is meant to show the place of origin of the Nonots who later multiplied and mingled with other plants. As a clan,nonot was built on the basis of kinship (blood relation) and one nonot is composed of several kanaf or families living togteher in one kuan (kampong or neighborhood). A kuan was, or probably is, generally located on top of a mountain or hill, the place believed to be the origin of the nonot ancestors. From the mountain, they spread in all directions The kanaf-kanaf forming anonot later clusttered in a residential location (neighborhood) and built a common dwelling. In performing his duties, an amaf (family head) was assisted by the heads of the kanafs (atoin amaf) then 
existing in his nonot. Along with the amaf, these kanaf heads became the leaders and protector of the nonot members (kolo-manu). The ume (home or household) was/is the smallest unit of the people's social structure and inside the ume live ama-aina (father and mother) dan oli-tataf (siblings, brothers and sisters). Nonot was the most important element in the social structure of Molo traditional people, and it can be said that the original government system of these people emanated from the nonot life (Timo, 2005:17-20).

\section{Government of Oenam Kingdom}

The region of Molo was one of the areas under the control of King Sonbai of Oenam kingdom. The Oenam territories were large, covering Biboki, Lelogama, Kapan, Camplong up to Babau-Kupang. A ruling king or chief of Oenam was called usif or kinga. An Usif held a very respectable position. He was considered to be the reincarnation of the heaven/sky god (uis neno) and the earth god (uis afinit), sand therefore when the king ordered anything his subjects would not disobey. The king and the nobles (uis neno/afinit and the landlord and their decendants (children and grand children) were unconditionally obeyed. They were viewed by the communities /people as the party entiled to control and possess anything available in their regions, including the lives and belongings of their subjects (people) (Kase, 2004:18). The people had to pay homage every year. This homage was demanded from the people as a result of a concept stating that an usif is the owner of the land. It was the usif who gave the seedlings and kept their people prosperous and protected from disasters. In addition, the people also had to make available and maintain an etu (legacy garden/kebun pusaka) to met the needs of the kingdom and were obliged to work for 14 a year as a abeat (worker of the king) for the interest o the king. In one year the number of abeat could reach 225,000 and they worked as the etu and abeat for the king (Timo, 2005:26).

\section{Zuid Midden Timor during the Colonial Era (1905-1942)}

The Dutch Government in Kapan (1905-1916)

Following the end of Bipolo War, King Boab Sonbai (Sobe Sonbai III) was exiled to Waingapu, and the Government of the Dutch East Indies was once again rejected by the local soldiers (me) of Nunbena and Mutis - Baki-Fobia, Tafin-Poli, Tae-Uki, Kau Fobia, Foan Olin, Aki Aobesi and Bait Kaunan. This war was called Nefobesak War by the local people. This war claimed a great number of casualties from the local communities and the local soldiers (meo) finally decided to surrender to the Dutch.The government of the East Indies established the Molo kingdom before all the Moloans, and appointed To Lukemtasa and Bait Kaunan as the deputy or caretaker of the Government of the East Indies in the Molo kingdom. They were both elected as a fetor. To Lukemtasa became the fetor of Netpala and Bait Kaunan was elected the fetorof Numbena (Timo, 2005:70).

The Government of the East Indies determined the the governemnt center was located in Kapan and build residential houses for the Dutch military officials at 
O'besi. The king of Molo, To Lukemtasa, and all his subordinates were later forced to sign a verklaring on August $15^{\text {th }}, 1907$. The content of the verklaring was multifaceted : First To Lukemtasa recognized that the region of Molo was a territory of the Dutch Government; thereby the people of Molo had to be loyal to the Dutch queen and acknolwedeged that the governor general as the highest representative of the Dutch Government. Second, To Lukemtasa would comply with the Dutch political policies with foreign countries, meaning that an anemy to the Dutch would the king's enemy and a friend to the Dutch would be his friend, too. Third, To Lukemtasa all the region under his rule would be suject to and abide all the instructions given by the Dutch Queen or her representative in the East Indies. The Dutch also re-organized its administrative regions in the landschap of Molo by forming two fetor administrative government units, the Netpala and Nunbena fetor administrative governments. In response to the suggesstion from usif To Lukemtasa the Dutch Government agreed to establish another two fetor administrative government unit, the Bijeli and Mutisfetor administrative governments. The establishment of a fetor administrative government unitand the inauguration of fetor in every fetor adminstrative government unit(kefetoran) was performed by the king of Molo, acting upon the permission and discretion of the Dutch Government.

With regard to the government of Molo kingdom, the Dutch Government did elter the exixting local traditional governmental system but restructured the local government and adopted terms coming from external language such fetor and temukung and inserted them in the structure of the governement of the kingdom. (Fetor comes from the Portuguese feitor meaning and region ruler), and temukung comes from a Javanese word "tumenggung" (Middelkop, 1960:21). The Dutch determined the king as the top leader, under the king were the fetors serving as the kings assistants in every fetor administrative governmental unit Indonesian: kefetoran ) (Timo, 2008:28). To cover the entire areas of a kefetoran, afetor was assisted by atemukung who dwelled in every kampong. To supervise the government of the kingdom, the Dutch East Indies' Government posted a controleur whose job was to upervise every kingdom. The first Controleur serving in Kapan was Telep (Kase, 2004:17).

\section{The Dutch Government in SoE from 1917 to 1942}

In exercising its government, the Dutch also passed orders to assemble all weapons then in the possession of the people and issued a regulation stating that every adult was required to pay a 1.5 gildersand to in the forced labor. Only Molo landschap obeyed this regulation, Amanuban and Amanatun landschaps disobeyed. Both landschaps were considered to have rebelled or been dissenting to the regulation of the The East Indies Governement (Hand Itta, 2006: 35). As a result the Dutch Government send troops to conquer these two regions. Through Kapan, the Dutch troops tried to defeat Amanuban and Amanatun in the so called Niki-niki, Kolbano and Fotilo Wars. The region of Amanuban was under the rule usif Nope. Amanatun, 
which was composed of two small clans, the Nitibani and Bana clans grew into four clans Nitibani, Bana, Nenabu, and Misa.

After these two regions declared defeat in the war, they were treated the same as Molo region was.Amanuban Landschaphad to sign a verklaring on February $24^{\text {th }}$, 1923 and Amanatun landschap on February 24, ${ }^{\text {th }}$ 1923. After the execution the verklaring by the three regions Molo, Amanatun and Amanuban, the Dutch Government domiciled in Kupang reorganized the government by establishing Timor Residency and its vasals (Residentie Timor en onderhorigheden) specially the afdeling of Timor. The Afdeling of Timor ruled over the onderafdeling of Kupang,onderafdeling of Zuid Midden Timor (South-Middle Tomor), and onderafdeling of Noord Midden Timor (North Middle Timor) respectively led by a Dutch controller (controleur). Zuid Midden Timor consisted of three landschaps previously established by the Dutch, the Molo, Amanuban, Amanatun landschaps (Widiyatmika, 2010:166). In exercising the government in Kapan, Telep realized the the capital city was located far away from the other regions, Amanuban and Amanatun. Telep then had an initiative to move the capital city of Zuid Midden Timor to SoE. The plan to relocate the capital of Zuid Midden Timor was only accomplished in 1919.

As the preparatory step to move the capital city to SoE, devegetation was the first thing done as most of the the areas of SoE were forests. The wood produced by the devegetation was used as the materials to build dwellings for the Dutch soldiers and the residence of controleur Telep (Kase, 2004:55). The new capital of Zuid Midden Timorbegan to be slowly designed to become a center of the Ducth Governemnt in inland regions of Timor. To build streets, the people were forced to work without pay (Indonesian:kerja rodi) under the supervision of the miltary soldiers. However, until the Dutch left SoE in 1942, only 2 (two) kilometers of the streets was asphalted (from the cemetery near Maranatha Church toward Gunung Mas Store ( Gunung Mas), and bend toward Catholic Church and around Kampung Baru), the rest was soil. Apart from the street, the Dutch also brought in people from outside Timor who were obedient and loyal to the Government of the East Indies. These were people of Rote and Sabu islands, who later established neighborhoods and mingled with the local communities (Kase, 2004:56). These neighborhoods still exist until today and are called Kampung Rote and Kampung Sabu. The Chinese who were already there at that ttime preferred to live in the city center and engaged in trade as their main livelihood. Although Soe had become the center of govenrment of Zuid Midden Timor since 1917, the actual governmental adminstration was formally performed there in 1922 which was signed with the planting of the banyan tree (Ficus benjamina) in from of the military housing complex of the Dutch troops on September $1^{\text {st }}, 1922$. The local community figure present on the occasion was L. Mella (deceased), N. Fobia (deceased), and M. Ollin (deceased) (Kase, 2004:57-58).

Apart from the colonial expansion, the Government of East Indies also conducted the missions to spread their religion through folk schools (volkschool) which were established and scattered in those three kingdoms. The bastions, churches and schools were built close to each other. This proves that churches and 
schools have been in existence side by side (Cooley, 1977:237). The concern of the East Indies to education in Zuid Midden Timor only began in 1912 with the establishment of a folk school (volkschool) in Nefokoko. This is provided in the state gazettes (staatsblad) of 1915 No. 620 and No. 621 mentioning that a number of missionary foundations (zending) were given a donations in the form of cash from the government to build schools for the people (Cooley, 1977:28). For the regions where the schools were already built by the zendings, the government would build and manage schools for the people (Itta, 2006:107). According to Memori Serah Terima Jabatan K.I.T de Neijsin 1934, many of the schools in Kupang and the inland regions were managed church parochicalorganizations (Soh, 2008:94). Other than the folk schools (volkschool) Nefokoko, the missionary institutions (zending) also built folk schools in different regions including Molo, which were at Bijeli (1916), Oepopo (1917), Nunbena (1918), Tobu (1928), and at SoE (1938). In the regions of Amanuban and Amanatun folk schools were also built in Niki-niki and Pene (1912), Nunkolo, Putain and Popi (1913), Ofu (1916), Manufui (1917), Kuanfatu and Nifu (1918) (Kase, 2004:52-53). Apart from folk schools, the Dutch East Indies government, via the zending, also built School Tot Opleiding voor Inlandse Leraar (STOVIL) in SoE in1931. STOVIL, a theological school for priests was started in Ba'a (on he island of Rote) in 1902, and its founder was Ds. Le Grand and Ds De Vries. Between 1918 and 1920 STOVIL was presided by Duiverman, and was later followed by Ds. Waterink (19211923) and was chaired by Ds. Doupei from 1923-1931. During Ds. Doupei's tenure, this school was moved to Kupang (1931) after it was closed in 1926. The closing of this school, according to the Government of the Dutch East Indies was caused by an anti-Dutch Government movement and this movement was responded by STOVIL (as a nationalist) and was supported by the school students. This school was reopened in SoE in 1936 was was led by Ds. Stap, Ds. Vermeulen and Ds. Munte (Soh, 2008:96).

In 1916 the Avengelists Missionarists (Pekabaran Injil or PI) entered the inland areas of Timorand, in the progress, received a predikant voorzitter in 1925, was domiciled in Kupang and supervised 7 areas (resort) consisting of Kupang, Camplong, Kapan, Rote and Sabu, Alor, Wanreli,and Serwaru. Each of these areas (resort) was led by a hulpprediker (preacher assistant). The first priest to enter the region of Kapan pendeta was Ds. Geerdink, but due to his weak condition caused by the fever then attacking Timor, was replaced by Ds. Krayer van Aalst who arrived in Kapan in December 1918 (Cooley, 1977:48). In performing the zending duties, Ds. Krayer explored the indland regions of Timor which was then full of forests and searched for native tribes and and served avengelism by telling stories. The local communities then living traditional life welcame the arrival of Ds. Krayer well and were very much willing to listen to the biblical stories he was telling. With every passing day, more and more local people knew him and were willing to be baptized. For days Ds. Krayer traveled long distances and continuously sent letters to the Netherlands writing about anyting he had encountered. His written letters were then posted in the magazine The Timor Bode. Until 1922 when Ds. Krayerwas replaced by 
Ds. P. Middelkoop, he had sent 52 letters titled "Letter from orKapan" "Surat-surat dari Kapan" (Aalst, 2016:2-31). At the time Ds. Middelkoop started his service at the resort of Kapan, it was recorded that 500 people had been baptized. During his long term of service, Ds. P. Middelkoop studied the language and culture of he people living in the inland parts of Timor.

\section{Effects of Colonial Government}

Cultural Effects

Before the Dutch East Indies established a government center in Kapan, the people of Molo had lived traditionally and believed in Animism and Dinamism. Such beliefs were manifested in the different practices such as the highest level as the belief of their ancestors, belief in magic (supernatural power), life to death (kepercayaan sehidup semati), and a legend on the orign of plants (Widiyatmika, 2008:71-116). They believed that every object contains a power adverse to human but also a power that increases welbeing. In its progress, the people would try to find the tools to control the powers and direct them only to increase the welfare of the people. Another practice was the worship to gods and spirits of the ancestors in every ceremony held to entice the gods and spirits of their ancestors so that they would the offerings and grant their requests to improve their welfare (Kruyt, 2008:223). During the colonial time, the bilefs of the local people of the Zuid Midden Timor slowly changed, from the traditional animism and dynamism to Christianity. The first people to convert were the kings and their families in 1918, which was later followed by the the kampong heads and their families (Aalst, 2016:48-53). The determining factors in the conversion of the people's beliefs were the powerful influences from the prominent figures, such as the kings and the relentless efforts by the zendinggroups. In addition, the teachings of Christianity contained many thing $s$ in common with the traditional beleifs previously confessed by them, such as the belief in the super being and consequently the people could easily accept Christianity.

In addition to the conversion of the people's traditional beliefs, names were also changing from the local (traditional) names to Western names or Hebrew names. Before the introduction of western civilization, it was very difficult to understand and differentiate Tomorese names. In their traditions, the difference abetween the male names and female names was placed in the prefix, Nai for males and Bifor females. For example, if an expectant mother about to give birth to baby girl has a dream of is whisphered by her ancestor named Nai o Oematan, after the birth, the baby would be named Bi To Oematan. The conversion of names was made for the reason that the opeple living in Zuid Midden Tomor encountered difficulty when arranging for civil administration, such as the birth certificate. When someone was about to be baptized or reaches the age of schooling, a birth certificate is required because the name written in the birth certificate would be used to record the name in the Certificate of Baptism and in the school certificate. In general, the people of the Zuid Midden Timor welcame this name conversion because these people fully obeyed their kings (uis pah). For example, in 1918 when King Molo and his family were 
willing to be baptized, the kampong heads (under his rule) wer also willing to be baptized, along with their family (Aalst, 2016:48-53). After being baptized, the king'sname Lay A Kun (Tabelak-Oematan) was changed into Welem Frederik Henderik Oematan, and the names of the children of the king then also baptized were changed into Welem Cornelis Henderik Oematan and Samuel Soleman Henderik. The kampong heads who were also baptized changed their names into European or Hebrew names without knowing the meanings of the new names. Although people had to change their given nmes in the baptism, they still ratained their family names, which was the pride of their ancertral culture and has been maintained up to the present

\section{Education Effects}

The presence of the Dutch Colonial Government in Zuid Midden Timor has also left its impacts on education. People who previously only knew traditional non-formal education were introduced to formal education. In the formal education the people studied farming, hunting, war tactics, and so forth. After the East Indies occupied Kapan in 1907, they subsequently built 17 folk schools in Nefokoko, Bijeli,Oepopo, Nunbena, Tobu, SoE, Niki-niki, Pene, Nunkolo, Putain, Popi, Ofu, Manufui, Kuanfatu and Nifu. Since then th people began to learn how to read and write. However, not all children were allowed to go to schools established by the Government of the East Indies. This prohibition was mostly imposed on girls. In general the people of Zuid Midden Timor thought that girls had to be taught how to knit with the hope that they would be a able to produce woven clothes for their families. Also, they would be able to help their parents with the work in farms or kitchen if they did not go to school. For this reason, girls were given extra sklils such as weaving yarns, coloring, clinging yarns into the mill and learn how to weave. Altough the formal education introduced to the people was limited to folk school level, this was such a grea progress for the local communities eventually enjoyed/received the formal education system.

\section{Socio-Economic Effects}

The people in Zuid Midden Timor, specially in Molo,were a society composed of clan groups and ddwelled in the kuan (kampong) located on mountains of stony hills. Each of these clans was led by a clan chief (amaf). The social relationship created was based on the kinship system. The presence of the Government of the East Indies in the inland regions of Timor island had both psotive and negative effectson the socioeconomic life of the people in Zuid Midden Timor.

When the East Indies first occupied Kanpan as its pioneering step stone for the government cin the inland regions of timor, he people then living on the mountains and stony hills were ordered to go down and live on the sides of the military street that would later become the main street on the sides of the military they formed new nonot (neighborhoods). On the other hand, the kuan of the origin of their ancestors were slowly abandoned. This abandonment has led to the difficulty of retracing the 
traditional social structure of the life of the people of Zuid Midden Timor. Nevertheless, the position of the local chiefs, like the amaf, has been maintained.

The Government of East Indies also brought in people from outside the island of Timor, who were loyal to the Governmenth, such as people from Rote and Sabu islands. Some of these newcomers worked as governemnt officials for the colonial government, such as teachers. Some others, following suit the earlier immigrants, were engaged in commerce. These newcomers later formed groups in each of the government centers, both in Kapan and in SoE. They would then mingled with the local communities and some of them even entered into marital relationships. These groups grew rapidly and the locations of their residential neighborhood have been known as kampung Rote and kampung Sabu (Rote and Sabu kampongs).

In the field of economy, Zuid Midden Timor had undergone a considerable growth. This can be seen in the availability sandalwood trade posts representing 30x8 meter kiosks. These kiosks in its progress became the locations of daily marketsso the people did not have $t$ walk to the resident's capital city to sell their agricutural and farming products. The construction of daily market was contiuously done up to the inland parts of the island of Timor, particularly in Molo. This was closely associated with the growth of the colonial economy in Molo. To improve people's life, the Government of East Indies imported Balinese cows to Tomor island in 1912, using the turn system. This had positive effects on the people of Zuid Midden Timor. Although the king had taken over the sandalwood trade, the Balinese cow husbandry had produced changes (improvement) in the economy of the people. Until the Dutch Government finally left Timor, the Balinese cow husbandry had become one of the side source of livelihood owned by every family.

\section{Conclusion}

The island of Timor has been known since the ancient trade around $12^{\text {th }}$ century and the Zuid Midden Timor, as the colonial capital in inland Timor, has been known for the past century. The lack of the importance of archive has led to difficulty in conducting historical retracing of the inland parts of Timor conducted by historians studying Timor. One of the obstacles is that prior to the arrival of the Dutch East Indies in Molo, the local people of inland Timor but only knew the verbal story telling system, so the efforts to know what happened in Molo at that time were done only by interviews. As a consequence, the understanding of the history of the Zuid Midden Timor has been obscure and speculative, making it so distant in the collective memory of the people. Therefore, the history of the Zuid Midden Timor during the colonial era becomes one of the alternatives for historical writing. By viewing what happened in Moloin century ago, it is hoped that the public will understand how far the Government of the Dutch East Indies had expanded its colonization in Molo, a small town in the inland part of the island of Timor, which has almost never been studied in historical subjects in so far.

Since it was controlled by the Dutch, Mole has undergone substantial changes, from small kampongs or neighborhoods to a colonial capital city in inland Timor. All 
governemntal administration and economic avtivities were centered in Molo. The history of Zuid Midden Timorduring the colonial era clearly shows how vital the roles of the colonial government in the development of Molo. Unfortunately, the arrival of the Dutch was intendd to exploit the resources in Molo, which has led to Molo's being unable to grow up to the present day. The sandalwood trees or the wood, which was then the main natural resource and identity marker for the people in the inland parts of Timor island were almost extinct in 1942 when the city of SoE was occupied by the Japanese troops.

\section{References}

Aalst, Krayer (2016). Surat Surat Dari Kapan, Benih Cinta Kasih Allah Dalam Budaya Atoni, translated by Ebenhaizer I. Nuban Timo. Salatiga: Fakultas Teologi Universitas Kristen Satya Wacana.

Kase, Alfred (2004). SoE Potret Masa Lampau dan Kini. SoE: without publisher.

Kruyt, A. C. (2008). Keluar Dari Agama Suku Masuk ke Agama Kristen-Van Heiden tot Christen. Jakarta: PT. BPK Gunung Mulia.

Middelkop, P. (1960). Curse-Retribution-Enmity as Data in Natural Religion Expecially in Timor, Confronted with the Scripture. Amsterdam: Drukkerij en Uitgeverij Jacob Van Campen.

Parimarta, I Gde (2016). Perdagangan dan Politik di Nusa Tenggara. Yogyakarta: Penerbit Ombak.

Timo, Eben Nuban. (2005). Sistem Pemerintahan Tradisional di Timor Tengah Selatan. Kupang: UPTD Arkeologi, Kajian Sejarah dan Nilai Tradisional NTT.

(2008). Etnografi Atoin Pah Meto. Kupang: UPTD Arkeologi, Kajian Sejarah dan Nilai Tradisional Provinsi NTT

Widiyatmika, Munandjar (2007). Lintasan Sejarah Bumi Cendana. Kupang: Pusat Pengembangan Madrasah.

(2008). Kebudayaan Masyarakat di Bumi Cendana, Kupang: Pusat Pengembangan Madrasah NTT.

(2008). Laut Timor dan Sungai Benain dalam Perspektif Perkembangan Sosial Politik di Timor Barat pada Abad 17, Kupang: MSI NTT.

(2010). Kupang dalam Kencah Persaingan Hegemoni Kolonial Tahun 16531917. Kupang: Pusat Pengembangan Madrasah.

(2014). Cendana dan Dinamika Masyarakat Nusa Tenggara Timur. Yogyakarta: Penerbit Ombak. 